\title{
Protective Effects of Lactobacillus rhamnosus GG on Aflatoxins-Induced Toxicities in Male Albino Mice
}

\author{
Deabes M M ${ }^{1 *}$, Darwish H R², Abdel-Aziz K B², Farag I M², Nada SA ${ }^{3}$ and Tawfek N S
}

${ }^{1}$ Food Toxicology and Contaminants Department, National Research Centre, 33-El Bohouth street-Dokki, Cairo, Giza 12311, Egypt

${ }^{2}$ Cell Biology Department, National Research Center, 33-El Bohouth street-Dokki, Cairo, Giza 12311, Egypt

${ }^{3}$ Pharmacology Department, National Research Center, 33-El Bohouth street-Dokki, Cairo, Giza 12311, Egypt

${ }^{4}$ Zoology Department, Faculty of Science, Al-Minia Uni., Egypt

\begin{abstract}
The effects of sub-acute exposure (7 days) to aflatoxins and the potential protective effects of Lactobacillus rhamnosus GG ATCC53013 (LGG) were studied in male Albino mice. Four experimental groups were used, each comprising 30 mice; control group, LGG-treated group $\left(1 \times 10^{10} \mathrm{CFU}\right)$, AFs-treated group $(0.7 \mathrm{mg} / \mathrm{kg}$ b.w.), and a group given LGG two hours before AFs intoxication. The malondialdehyde (MDA), glutathione (GSH) levels and superoxide dismutase (SOD) activity were measured in liver and kidney tissues. Chromosomal aberrations in bone marrow and in spermatocytes, as well as mitotic and meiotic activities were performed to assess the genotoxicity; besides sperm parameters were evaluated. Results showed that AFs significantly elevated the tissue levels of MDA, whereas the levels of GSH as well as SOD activity were significantly decreased in liver and kidney. AFs increased significantly the frequencies of structural and numerical chromosome aberrations in bone marrow and spermatocytes. In addition mitotic and meiotic activities of somatic and germ cells were declined significantly. Also, AFs caused a high significant reduction in cauda epididymal sperm count, sperm motility and significant increase sperm abnormalities, as compared to control. Mice received LGG before AFs gavage, showed a significant amelioration in oxidative status in both liver and kidney, by increasing the contents of GSH and SOD activity. Cytogenetic analyses revealed that LGG administration before AFs gavage significantly reduced frequencies chromosomal aberrations in bone marrow and spermatocytes, and recovered mitotic and meiotic activities as well. Moreover, gavage LGG before AFs intoxication caused significant recovery in all sperm parameters studied. In conclusion, LGG was found to be safe and successful agent counteracting the oxidative stress and protected against the genotoxicity induced by AFs, in addition to reduction in spermatotoxic alterations.
\end{abstract}

Keywords: Aflatoxin; Lactobacillus rhamnosus; Oxidative stress; Chromosome; Spermatocytes; Sperm

\section{Introduction}

Aflatoxins (AFs) are naturally-occurring mycotoxins, produced as secondary metabolites by the fungus Aspergillus flavus, A.parasiticus, and A. nominus; and are direct contaminants of cereals, grains, nutsand fruits [1]. More than 5 billion people in developing countries worldwide are at risk of chronic exposure to naturally occurring aflatoxins [2]. Aflatoxins are potent mutagenic, carcinogenic, teratogenic, hepatotoxic and immunosuppressive toxins, and also inhibit several metabolic systems, causing liver, kidney and heart damage [2-5]. $\mathrm{AFB}_{1}$ is the most potent of the known AFs, and is a classified within class 1 of human carcinogens [6]. Although the liver is clearly the principal target organ for $\mathrm{AFB}_{1}$, kidney and testis can also be a target following dietary and inhalational exposure. Also, AFs have been detected in boar sperm and the human semen $[7,8]$. $\mathrm{AFB}_{1}$ is activated by cytochrome $\mathrm{P} 450$ enzyme system to produce a highly reactive intermediate, AFB1-8,9-epoxide, which subsequently binds to nucleophilic sites in DNA forming 8,9-dihydro-8-(N7guanyl)-9-hydroxy- $\mathrm{AFB}_{1}$ adduct, which is regarded as a critical step in the initiation of $\mathrm{AFB}_{1}$-induced carcinogenesis $[9,10]$. In addition, the $\mathrm{AFB}_{1}$-associated mutagenesis was suggested to represent a plausible cause for the higher chromosome instability observed in Chinese Hepatocellular Carcinomas, when compared with European primary liver carcinomas [11].

Several reports suggested that toxicity might ensue through the generation of intracellular reactive oxygen species (ROS) like superoxide anion, hydroxyl radical and hydrogen peroxide $\left(\mathrm{H}_{2} \mathrm{O}_{2}\right)$ during the metabolic processing of $\mathrm{AFB}_{1}$ in the liver. These ROS may attack soluble cell compounds as well as membranes, eventually leading to the impairment of cell functionality and cytotoxicity $[12,13]$. Recently, $\mathrm{AFB}_{1}$ also has been shown to induce lipid peroxidationassociated liver and kidney damage in vitro and in vivo [14-16].

Concerns related to the negative health impacts of AFs have lead to the investigation of strategies to eliminate, inactivate or reduce the bioavailability of these toxins in contaminated products. Probiotics are defined as "live microorganisms which, when consumed in adequate amounts as part of food, confer a health benefit on the host" [17].

Lactic acid producing bacteria (LAB), particularly lactobacilli and bifidobacteria are considered as the most probable agents responsible for these effects. Probiotics have been proved to exert healthpromoting influences in human and animals $[18,19]$. Kruszewska et al. [20] measured total antioxidant activity of some lactobacilli with a colorimetric assay; $P$. pentosaceus and L. plantarum 2592 produced antioxidants after $18 \mathrm{~h}$ growth corresponding to $100 \mu \mathrm{g}$ vitamin C. Also, LAB is of particular interest for reducing the bioavailability of

*Corresponding author: Mohamed M. Deabes, Food Toxicology and Contaminants Department, National Research Centre, 33-El Bohouth street-Dokki, Cairo, Giza 12311, Egypt, E-mail: mydeabes@yahoo.com

Received January 12, 2012; Accepted March 12, 2012; Published March 14 2012

Citation: Deabes MM, Darwish HR, Abdel-Aziz KB, Farag IM, Nada SA, et al. (2012) Protective Effects of Lactobacillus rhamnosus GG on AflatoxinsInduced Toxicities in Male Albino Mice. J Environment Analytic Toxicol 2:132. doi:10.4172/2161-0525.1000132

Copyright: (c) 2012 Deabes MM, et al. This is an open-access article distributed under the terms of the Creative Commons Attribution License, which permits unrestricted use, distribution, and reproduction in any medium, provided the original author and source are credited. 
AFs, where a number of studies have screened these microorganisms for the ability to bind to AFs and have reported a wide range of genus, species and strain specific binding capacities [21-24]. Currently there is considerable interest in the potential antigenotoxic and anticarcinogenic effects of probiotics. Lactobacillus rhamnosus $G G$ (LGG) is one of the best-studied probiotic bacteria in clinical trials for treating and/or preventing several intestinal disorders, including inflammatory bowel diseases and diarrhea $[25,26]$. Furthermore LGG efficiently binds, in vitro, several mycotoxins, including aflatoxin $B_{1}$ and aflatoxin $\mathrm{M}_{1}[27,28]$. In an in vivo study using the chicken duodenum loop technique, LGG removed as high as $54 \%(\mathrm{w} / \mathrm{w})$ of the added $\mathrm{AFB}_{1}$ and reduced intestinal adsorption by $73 \%(w / w)$ [29]. Moreover, PoolZobel et al. [30] demonstrated the ability of L. casei Shirota to inhibit DNA damage in the colon of rats exposed to the mutagen $N$-methyl- $N$ nitro- $N$-nitrosoguanidine (MNNG). A subsequent study confirmed the antigenotoxic effects for different species of lactobacilli in rats against the colon carcinogen 1, 2-dimethyl hydrazine; this antigenotoxic activity was species specific. Gratz et al. [31] showed that pre-exposure of LGG to $\mathrm{AFB}_{1}$ reduced its binding ability with intestinal mucus, resulting in faster removal. It had been claimed that LAB which are contained in fermented foods and are part of the intestinal microflora may protect human against colon cancer [32,33].

So, minimizing the possible deleterious effects resulting from human and animals exposure to genotoxic and/or carcinogenic agents in our environment is of utmost need. The aim of the present study was to evaluate the in vivo antioxidant, antigenotoxic and antispermatotoxic effects of lactic acid bacteria, Lactobacillus rhamnosus GG (ATCC 53013), against the well-known mycotoxin AFs in male Albino mice.

\section{Materials and Methods}

Chemicals, reagents, and reagent kits, used in the present study were purchased from Riedel-de Haën, Germany and Biodiagnostic, Cairo, Egypt. Crude aflatoxins $B_{1}, B_{2}, G_{1}$ and $G_{2}$ were obtained as crude mycotoxins were determined by HPLC, Food Toxicology and Contaminants Dept., National Research Center, Egypt.

\section{Determination of aflatoxin by HPLC}

Apparatus: The HPLC system consisted of Waters Binary Pump Model 1525, a Model Waters 1500 Rheodyne manual injector, a Watres 2475 Multi- Wavelength Fluorescence Detector, and a data workstation with software Breeze 2. A phenomenex C18 (250 x 4.6 $\mathrm{mm}$ i.d.), $5 \mu \mathrm{m}$ from Waters corporation (USA). An isocratic system with water: methanol: acetonitrile 240:120:40 [34]. The separation was performed at ambient temperature at a flow rate of $1.0 \mathrm{~mL} / \mathrm{min}$. The injection volume was $20 \mu \mathrm{L}$ for both standard solutions and sample extracts. The fluorescence detector was operated at wavelength of 360 $\mathrm{nm}$ for excision and $440 \mathrm{~nm}$ for emission.

\section{Derivatization}

The derivatives of sample extract and standard were done as follow: $100 \mu \mathrm{l}$ of trifluoracetic acid (TFA) were added to samples and mixed well for $30 \mathrm{~s}$ and the mixture stand for $15 \mathrm{~min}$. $900 \mu \mathrm{l}$ of water: acetonitrile $(9: 1 \mathrm{v} / \mathrm{v})$ were added and mixed well by vortex for $30 \mathrm{~s}$ and the mixture was used for HPLC analysis.

\section{Experimental animals}

Male Swiss Albino mice (Mus musculus) three months old weighing 25-30 grams were obtained from the animal house colony,
National Research Center, Giza, Egypt. The animals were maintained on standard casein diet and water ad libitum and housed individually in a temperature-controlled and artificially illuminated room free from any source of chemical contamination.

\section{Bacterial strain and culture preparation}

Lactobacillus rhamnosus strain GG (ATCC 53013) was a kind gift provided by Food Toxicology and Contaminants Dept., National Research Center, Egypt, as lyophilized powder and stored at $-80^{\circ} \mathrm{C}$. LGG cultures were prepared according to the procedure of El-Nezami et al. [35]. In which, bacterial cultures of LGG were obtained by incubating $0.1 \mathrm{~g}$ of lyophilized bacteria in $10 \mathrm{ml}$ of deMan-RogosaSharpe (MRS) broth under aerobic conditions at $37^{\circ} \mathrm{C}$ for $24 \mathrm{~h}$. The number of lactic acid bacteria cells was enumerated by serial dilution in peptone water $(0.1 \% \mathrm{w} / \mathrm{v})$ and plate counts on deMan-Rogosa-Sharpe agar (MRSA) medium.

\section{Experimental design}

Mice were randomly divided into four groups each consisting of 30 mice, each group was divided into three subgroups (10 mice for each). Animals were treated orally for successive 7 days as follows: (1) untreated control given corn oil and MRS broth daily, (2) treated with AFs $\left(0.7 \mathrm{mg} / \mathrm{kg}\right.$ b.w.) in $0.4 \mathrm{ml}$ corn oil, (3) treated with LGG $\left(1 \times 10^{10}\right.$ $\mathrm{CFU})$ in MRS broth and (4) treated with the LGG $\left(1 \times 10^{10} \mathrm{CFU}\right) 2$ hours before AFs gavage $\left(0.7 \mathrm{mg} / \mathrm{kg}\right.$ b.w.). On the $8^{\text {th }}$ day of the study, the $1^{\text {st }}$ subgroup was killed and femoral bones were removed, stripped and cleaned from extraneous tissues. Also, liver and kidney samples were dissected out and washed immediately with ice-cold saline to remove as much blood as possible, and then stored immediately at $-80^{\circ} \mathrm{C}$ until analysis. On the $15^{\text {th }}$ day of the study, the $2^{\text {nd }}$ subgroup was killed and both testes removed and washed in warm citrate saline. At the end of the experiment $\left(35^{\text {th }}\right.$ day), cauda epididymis, of the $3^{\text {rd }}$ subgroup, were quickly isolated, blotted free of blood and utilized for the analysis of various reproductive parameters.

\section{Biochemical analyses}

Measurement of lipid peroxidation: Liver and kidney tissues were homogenized individually in $20 \mathrm{~mm}$ Tris- $\mathrm{HCl}$ ( $\mathrm{pH}$ 7.4). Homogenates were centrifuged at $6000 \mathrm{~g}$ for $30 \mathrm{~min}$. MDA levels in the supernatants were determined using a spectrophotometric assay kit according to the manufacturer's instructions. Briefly, thiobarbituric acid (TBA) reacts with MDA in acidic medium at temperature of $95^{\circ} \mathrm{C}$ for $30 \mathrm{~min}$ to form thiobarbituric acid reactive product. The absorbance of the resultant pink product can be measured at $534 \mathrm{~nm}$ [36]. The lipid peroxidation values are expressed as $\mathrm{nm} \mathrm{MDA} / \mathrm{mg}$ tissue.

Reduced glutathione (GSH) content: GSH levels were measured using a spectrophotometric assay kit according to the manufacturer's instructions. 5,5 dithiobis-2-nitrobenzoic acid (DTNB) is reduced by glutathione (GSH) to produce a yellow compound. The reduced chromogen directly proportional to GSH concentration and its absorbance can be measured at $405 \mathrm{~nm}$ [37]. GSH values are expressed as $\mathrm{mmol} / \mathrm{g}$ tissue.

Superoxide dismutase (SOD) activity: Liver and kidney homogenates were prepared in cold Tris $-\mathrm{HCl}(5 \mathrm{mmol} / \mathrm{L}$, containing 2 $\mathrm{mmol} / \mathrm{L}$ EDTA, pH 7.4) using a homogenizer. The unbroken cells and cell debris were removed by centrifugation at $10,000 \mathrm{~g}$ for $10 \mathrm{~min}$ at $4^{\circ} \mathrm{C}$. The supernatant was used immediately for the assays for SOD. 100 $\mu \mathrm{l}$ of supernatants were added to $2.8 \mathrm{ml}$ tris HCL buffer containing $25 \mu \mathrm{l}$ pyrogallol and $20 \mu \mathrm{l}$ catalase [38]. The activities of all of these enzymes 
were determined. The SOD activities were expressed as units per mg of tissue.

Chromosomal aberrations examination: Metaphases for analysis of chromosome aberrations in bone marrow cells and spermatocytes were prepared according to the method of Perston et al. [39] and Evans et al. [40] and recommendations by Russo [41] were considered. Fifty metaphase spreads were analyzed per animal. For Mitotic activity of cells, the number of dividing cells were recorded and the mitotic index was calculated as the following formula: Mitotic index \% (M.I.) $=$ the number of dividing cells/total number of bone marrow cells counted/ per 1000 cells. For Meiotic activity of spermatocytes; meiotic index was calculated as the frequency of MII/MI, normal ratio should be equal 2 .

\section{Sperm parameters}

Sperm parameters were prepared and analyzed according to the protocols of Wyrobek and Bruce [42].

Epididymal sperm counts and sperm motility: Epididymal sperm counts and evaluation of the motility were performed visually using counting chamber. The count was repeated three times for each sample to minimize error, and calculated as $10^{6}$ per sperm dilution. Sperm motility was determined by counting both motile and non-motile sperms in at least 16 separate and randomly selected fields. These results were expressed as percent motility.

Epididymal sperm morphology: A drop of sperm suspension was smeared onto a slide, left to dry; then stained with Eosin A, the slides were washed in water and air dried again. The smears were microscopically analyzed at a magnification of $\times 1000$ for observation of abnormalities.

\section{Statistical analysis}

Statistical analyses were performed by one-way ANOVA followed by Tuckey's test or by Two-way ANOVA followed by Bonferroni's test comparing all groups. Analysis was conducted with GraphPad Prism software V.5.0.3 (Inc., San Diego, CA; USA).

\section{Results}

In AFs-treated mice, the level of MDA in liver and kidney tissues were significantly increased compared to control and LGG groups at $\mathrm{P}<0.01$ (Table 1 ). In contrast, mice receiving LGG alone, showed a significant reduction in MDA levels, when compared with control at $\mathrm{P}<0.01$. Furthermore, the LGG gavage before AFs treatment caused a significant reduction in MDA levels in both liver and kidney tissues compared to AFs-treated group at $\mathrm{P}<0.01$. In this group, the levels of
MDA in liver and kidney tissues were significantly higher than that of control group $(\mathrm{P}<0.01)$.

On the other hand, mice given LGG alone exhibited increase in GSH content as compared to control, which was insignificant at $\mathrm{P}>0.05$ in case of liver and significant at $\mathrm{P}<0.05$ in case kidney tissues. GSH was markedly depleted in liver and kidney tissues of mice administered AFs, by $64 \%$, in comparison with control; this reduction was statistically significant at $\mathrm{P}<0.01$. A significant increase in GSH level was shown in mice received LGG before AFs gavage when compared with AFs group at $\mathrm{P}<0.01$. This enhancement was significantly below that of control and LGG groups.

SOD activity in liver and kidney tissues was significantly decreased in $\mathrm{AFs}$ group, as compared to all groups at $\mathrm{P}<0.01$. However, the activity of SOD in LGG plus AFs group was significantly increased as compared to the AFs group (Table 1). This increase was still significantly below that of control in kidney tissues at $\mathrm{P}<0.05$. Again, mice received LGG alone showed an enhancement in SOD activity which was significant in liver tissue at $\mathrm{P}<0.01$ and in kidney tissue at $\mathrm{P}<0.05$ when compared with the control group.

\section{Effects of LGG on AFs genotoxicity in bone marrow cells}

The present data showed that AFs induced both structural and numerical chromosomal abnormalities. Table 2 represents the mean values of different types of chromosomal aberrations induced by AFs in bone marrow cells of male mice. Structural chromosomal aberrations recorded were chromatid breaks, chromatid gaps and deletions. The results showed a high significant increase in frequencies in chromatid breaks, gaps, deletions and fragments; while chromatid breaks, deletions and gaps showed a high statistical significant increase at $\mathrm{P}<0.001$, accentric fragments were only statistically significant at $\mathrm{P}<0.05$ when compared with control. Total structural aberrations showed high significant increase at $\mathrm{P}<0.001$. On the other hand, AFs induced very high incidence in numerical chromosome aberrations, which were statistically significant at $\mathrm{P}<0.001$. Numerical aberrations were recorded as periploidy, premature centromere division (PCD) and polyploidy. Also, the total numerical aberrations was highly significant at $\mathrm{P}<0.001$.

Treatment with LGG before AFs-intoxication significantly decreased the frequencies of structural chromosome aberrations (4 folds); this recovery was significant in comparison to the AFs group at $\mathrm{P}<0.001$ for chromatid breaks and gaps, and significant at $\mathrm{P}<0.01$ for the chromatid deletions and fragments. Regarding numerical aberrations, the frequencies of PCD, polyploidy and total numerical aberrations showed significant recovery when compared to the AFs

\begin{tabular}{|c|c|c|c|c|c|c|}
\hline \multirow{3}{*}{ Experimental Groups } & \multicolumn{6}{|c|}{ Parameters } \\
\hline & \multicolumn{2}{|c|}{$\begin{array}{c}\text { MDA } \\
\text { (nmoles /gm protein) }\end{array}$} & \multicolumn{2}{|c|}{$\begin{array}{c}\text { GSH } \\
\text { (mmol/gm tissue) }\end{array}$} & \multicolumn{2}{|c|}{$\begin{array}{c}S O D \\
\text { (units/mg protein) }\end{array}$} \\
\hline & LIVER & KIDNEY & LIVER & KIDNEY & LIVER & KIDNEY \\
\hline $\begin{array}{l}\text { Control } \\
\text { (Broth / corn oil) }\end{array}$ & $339 \pm 11.0^{A}$ & $258 \pm 5.62^{A}$ & $12.9 \pm 0.39^{A}$ & $17.0 \pm 0.34^{A}$ & $29.8 \pm 0.85^{A}$ & $69.0 \pm 1.35^{\mathrm{AB}}$ \\
\hline $\begin{array}{l}\text { AFs } \\
(0.7 \mathrm{mg} / \mathrm{kg} \text { b.w. })\end{array}$ & $787 \pm 9.31^{\mathrm{D}}$ & $702 \pm 12.7^{D}$ & $4.16 \pm 0.28^{c}$ & $9.22 \pm 0.36^{c}$ & $16.0 \pm 0.70^{c}$ & $34.8 \pm 1.98^{c}$ \\
\hline $\begin{array}{l}\text { LGG } \\
\left(1 \times 10^{10}\right)\end{array}$ & $284 \pm 7.73^{\text {B }}$ & $214 \pm 5.81^{\mathrm{B}}$ & $13.8 \pm 0.25^{A}$ & $18.9 \pm 0.54^{\mathrm{A}^{*}}$ & $37.0 \pm 1.49^{\mathrm{B}}$ & $78.2 \pm 2.69^{A^{*}}$ \\
\hline LGG plus AFs & $408 \pm 11.5^{c}$ & $322.0 \pm 3.39^{c}$ & $9.44 \pm 0.32^{\mathrm{B}}$ & $13.9 \pm 0.34^{\mathrm{B}}$ & $25.7 \pm 1.41^{\mathrm{A}}$ & $57.6 \pm 2.66^{\mathrm{B}^{*}}$ \\
\hline
\end{tabular}

- Means with different superscript letters $(A, B, C \& D)$ are significantly different $(P<0.01)$

- Means with a star are significantly different $(P<0.05)$

- All data are expressed as means \pm SEM

Table 1: Effect of $L G G$ on AFs-induced lipid peroxidation and antioxidative defense parameters in liver and kidney of male mice. 
Citation: Deabes MM, Darwish HR, Abdel-Aziz KB, Farag IM, Nada SA, et al. (2012) Protective Effects of Lactobacillus rhamnosus GG on AflatoxinsInduced Toxicities in Male Albino Mice. J Environment Analytic Toxicol 2:132. doi:10.4172/2161-0525.1000132

Page 4 of 9

\begin{tabular}{|c|c|c|c|c|c|c|c|c|c|c|}
\hline \multirow{2}{*}{$\begin{array}{l}\text { Experimental } \\
\text { Groups }\end{array}$} & \multicolumn{5}{|c|}{ Structural aberrations } & \multicolumn{4}{|c|}{ Numerical aberrations } & \multirow{2}{*}{$\begin{array}{l}\% \text { of Mitotic } \\
\text { activity }\end{array}$} \\
\hline & Breaks & Gaps & Deletions & Fragments & Total structural & $P C D$ & Peri-ploidy & Poly-ploidy & Total numerical & \\
\hline $\begin{array}{l}\text { Control } \\
\text { (Broth / corn oil) }\end{array}$ & $0.60 \pm 0.25^{A}$ & $\begin{array}{l}0.40 \pm \\
0.25^{A}\end{array}$ & $0.40 \pm 0.25^{A}$ & $0.40 \pm 0.25^{A}$ & $1.80 \pm 0.20^{A}$ & $\begin{array}{l}1.60 \pm \\
0.25^{\mathrm{AB}}\end{array}$ & $\begin{array}{l}0.80 \pm \\
0.20^{\mathrm{A}}\end{array}$ & $\begin{array}{l}1.00 \pm \\
0.32^{\mathrm{AB}}\end{array}$ & $3.40 \pm 0.51^{\mathrm{A}}$ & $100 \pm 0.00^{A}$ \\
\hline $\begin{array}{l}\text { AFs } \\
(0.7 \mathrm{mg} / \mathrm{kg} \text { b.w.) }\end{array}$ & $3.80 \pm 0.37^{B}$ & $\begin{array}{l}3.40 \pm \\
0.25^{\mathrm{B}}\end{array}$ & $2.60 \pm 0.25^{\mathrm{B}^{* *}}$ & $2.00 \pm 0.32^{A B^{*}}$ & $12.0 \pm 0.45^{c}$ & $8.0 \pm 0.45^{c}$ & $\begin{array}{l}3.80 \pm \\
0.37^{c}\end{array}$ & $\begin{array}{l}5.60 \pm \\
0.25^{\mathrm{c}}\end{array}$ & $17.4 \pm 0.68^{c}$ & $51.6 \pm 1.96^{D}$ \\
\hline $\begin{array}{l}L G G \\
\left(1 \times 10^{10}\right)\end{array}$ & $0.40 \pm 0.25^{\mathrm{A}}$ & $\begin{array}{l}0.60 \pm \\
0.25^{A}\end{array}$ & $0.60 \pm 0.25^{A}$ & $0.40 \pm 0.25^{A}$ & $2.20 \pm 0.20^{A}$ & $\begin{array}{l}1.00 \pm \\
0.32^{\mathrm{A}}\end{array}$ & $\begin{array}{l}0.60 \pm \\
0.25^{A}\end{array}$ & $\begin{array}{l}1.40 \pm \\
0.25^{A}\end{array}$ & $3.00 \pm 0.71^{\mathrm{A}}$ & $111.0 \pm 2.01^{B}$ \\
\hline LGG plus AFs & $0.80 \pm 0.20^{A}$ & $\begin{array}{l}1.20 \pm \\
0.37^{A}\end{array}$ & $0.80 \pm 0.20^{\mathrm{AB}}$ & $0.20 \pm 0.20^{A B^{* *}}$ & $3.00 \pm 0.45^{\mathrm{A}}$ & $\begin{array}{l}3.20 \pm \\
0.37^{\mathrm{B}^{*}}\end{array}$ & $\begin{array}{l}1.40 \pm \\
0.25^{A}\end{array}$ & $\begin{array}{l}2.60 \pm \\
0.40^{\mathrm{B}^{*}}\end{array}$ & $7.20 \pm 0.58^{B}$ & $82.2 \pm 1.28^{c}$ \\
\hline
\end{tabular}

- Means with different superscript letters $(A, B, C \& D)$ are significantly different $(P<0.001)$

- Means with two stars are significantly different $(P<0.01)$

- Means with a star are significantly different $(P<0.05)$

-All data are expressed as means \pm SEM

Table 2: Effect of LGG on chromosomal aberrations and mitotic activity induced by AFs in bone marrow cells in male mice.

group $(\mathrm{P}<0.001)$, but this recovery was still below the values of control and LGG groups.

PCD and polyploidy showed significant differences compared with the LGG and control groups at $\mathrm{P}<0.05$, while the total numerical aberrations showed significant difference at $\mathrm{P}<0.001$. On the other hand, treatment with LGG alone showed insignificant differences in chromosome aberrations in bone marrow compared to the control group at $\mathrm{P}>0.05$.

The mitotic index (Table 2) revealed a significant mitotic delay (51.6 $\%)$ in mice treated with AFs with respect to control group $(\mathrm{P}<0.01)$. In LGG group, mitotic activity showed a significant enhancements at $\mathrm{P}<0.01$ when compared with other groups. On the other hand, LGG gavage before AFs intoxication recovered the mitotic activity to about $82 \%$, this recovery was statistically significant $(\mathrm{P}<0.01)$ when compared to the AFs intoxicated group from one side and it was statistically below that of control at $\mathrm{P}<0.01$ from the other side.

\section{Effects of LGG on AFs genotoxicity in germ cells (spermatocytes MI, MII)}

Results of chromosomal abnormalities induced by AFs treatment in mice spermatocytes are presented in Table 3. X-Y and autosomal univalents were recorded as structural chromosome aberrations in metaphase I (MI), while numerical abnormalities were recorded in metaphase II (MII) as periploidy $(\mathrm{n} \pm 1,2)$ and polyploidy. Data clearly showed that AFs-intoxication induced very high significant increase in all types of structural and numerical abnormalities at $\mathrm{P}<0.001$.

In mice given LGG cultures before AFs-intoxication, structural aberrations were decreased significantly compared to the AFs-treated animals at $\mathrm{P}<0.001$. On the other hand, structural aberrations recovery was still above the values of control and LGG groups; autosomal univalents were statistically significant higher at $\mathrm{P}<0.05$ and the total structural aberrations increased significantly at $\mathrm{P}<0.001$, whereas no significant differences were found between this group and the control group for $\mathrm{X}-\mathrm{Y}$ univalents at $\mathrm{P}>0.05$. The $\mathrm{LGG}$ only treated group showed no significant differences in structure aberrations in respect to the control at $\mathrm{P}>0.05$.

AFs also, increased periploidy, polyploidy and the total numerical aberrations which were significant $(\mathrm{P}<0.001)$ compared to all other groups. Meanwhile, the LGG plus AFs group showed a significant reduction in numerical aberrations compared to the AFs-treated group $(\mathrm{P}<0.001)$. Aeuploidy and polyploidy showed significant increase when compared to other groups at $\mathrm{P}<0.05$, whereas the total numerical aberrations were significant higher compared to other groups at
$\mathrm{P}<0.001$. LGG only treated group showed no significant differences in numerical aberrations in respect to the control at $\mathrm{P}>0.05$.

The meiotic index (Table 3 ) revealed a significant meiotic delay in mice treated with AFs with respect to all other groups $(\mathrm{P}<0.001)$. LGG gavage before AFs treatment recovered meiotic activity to the baseline of control; meanwhile it showed a significant difference when compared with the LGG group at $\mathrm{P}<0.05$. In the LGG group, there were no significant differences observed compared with the control group at $\mathrm{P}>0.05$.

\section{Effects of LGG on AFs sperm toxicity}

Table 4 presented the data of sperm concentration, motility and morphology due to different treatments. AFs-intoxication caused a highly significant decrease in sperm concentration as compared to control at $\mathrm{P}<0.001$. On the other hand administration of LGG before AFs intoxication caused a significant increase in sperm count respect to the AFs-treated group $\left(19.6 \times 10^{6}\right)$; this enhancement showed no significant differences when compared to control group at $\mathrm{P}>0.05$, whereas this increase was significantly below that of LGG groups at $\mathrm{P}<$ 0.001. In mice given LGG alone, insignificant increase in sperm count was observed compared to the control at $\mathrm{P}>0.05$.

Sperm motility of mice intoxicated with AFs was affected dramatically, which was reduced to $34.0 \%$; this reduction was statistically highly significant at $\mathrm{P}<0.001$ compared to all groups. In LGG plus AFs group, there was a significant enhancement in sperm motility (69.0\%) when compared to the AFs-treated group. Again, this increase was still significantly below the basal count of the control at $\mathrm{P}<0.001$. LGG group showed no significant increase in sperm count in respect to that of the control at $\mathrm{P}>0.05$.

AFs treatment induced a high significant increase in sperm abnormalities $(81.0 \%)$ in comparing with control at $\mathrm{P}<0.001$ (Table 4 ). The various head abnormalities were existed, specially head without hook, unusual head shapes, big head and decapitation. The mid-piece abnormalities consisted of hair-pin, folded, bent heads and disrupted neck. The tail abnormalities essentially consisted of angular and bi- or coiled tail. In AFs-treated mice, $19.6 \%$ of sperm head was detached from the flagellum, which was significant higher compared to control at $\mathrm{P}<0.001$. In addition, AFs caused a fairly high percentage of sperm (18.4\%) that had sticky flagellum (agglutination), where several sperms remained fused in various numbers over short to long distances, it was significant higher compared to at $\mathrm{P}<0.001$. The retention of cytoplasmic droplet (CD) by the cauda epididymal sperm of control as well as AFs-treated mice was observed. The retention of CD by the cauda epididymal sperm was $10.0 \%$ in control mice whereas it was $40.8 \%$ in 
Citation: Deabes MM, Darwish HR, Abdel-Aziz KB, Farag IM, Nada SA, et al. (2012) Protective Effects of Lactobacillus rhamnosus GG on AflatoxinsInduced Toxicities in Male Albino Mice. J Environment Analytic Toxicol 2:132. doi:10.4172/2161-0525.1000132

Page 5 of 9

\begin{tabular}{|c|c|c|c|c|c|c|c|}
\hline \multirow[b]{2}{*}{$\begin{array}{l}\text { Experimental } \\
\text { Groups }\end{array}$} & \multicolumn{3}{|c|}{ Structural aberrations (MI) } & \multicolumn{3}{|c|}{ Numerical aberrations (MII) } & \multirow{2}{*}{$\begin{array}{l}\text { Meiotic } \\
\text { Index } \\
(M I I / M I)\end{array}$} \\
\hline & $X-Y$ univalents & $\begin{array}{l}\text { Autosomal } \\
\text { univalents }\end{array}$ & Total & Periploidy & Polyploidy & Total & \\
\hline $\begin{array}{l}\text { Control } \\
\text { (Broth / corn oil) }\end{array}$ & $1.60 \pm 0.25^{A}$ & $0.80 \pm 0.20^{A}$ & $2.20 \pm 0.20^{A}$ & $0.80 \pm 0.20^{\mathrm{A}}$ & $1.60 \pm 0.25^{\mathrm{A}}$ & $2.40 \pm 0.25^{\mathrm{A}}$ & $1.98 \pm 0.043^{A B}$ \\
\hline $\begin{array}{l}\text { AFs } \\
(0.7 \mathrm{mg} / \mathrm{kg} \text { b.w. })\end{array}$ & $4.80 \pm 0.37^{\mathrm{B}}$ & $7.80 \pm 0.37^{\mathrm{B}}$ & $12.6 \pm 0.51^{c}$ & $4.40 \pm 0.51^{\mathrm{B}}$ & $8.00 \pm 0.45^{B}$ & $12.4 \pm 0.75^{c}$ & $1.33 \pm 0.038^{D}$ \\
\hline $\begin{array}{l}L G G \\
\left(1 \times 10^{10}\right)\end{array}$ & $1.20 \pm 0.37^{A}$ & $0.80 \pm 0.37^{A}$ & $2.00 \pm 0.32^{A}$ & $0.60 \pm 0.25^{A}$ & $1.60 \pm 0.25^{A}$ & $2.20 \pm 0.37^{A}$ & $2.17 \pm 0.054^{\mathrm{BC}}$ \\
\hline LGG plus AFs & $2.00 \pm 0.32^{A}$ & $2.40 \pm 0.25^{A^{*}}$ & $4.40 \pm 0.25^{\mathrm{B}}$ & $2.20 \pm 0.20^{A^{*}}$ & $3.0 \pm 0.32^{A^{*}}$ & $5.20 \pm 0.37^{B}$ & $1.92 \pm 0.062^{\mathrm{AC}^{*}}$ \\
\hline
\end{tabular}

- Means with different superscript letters $(A, B, C \& D)$ are significantly different $(P<0.001)$

- Means with a star are significantly different $(P<0.05)$

-All data are expressed as means \pm SEM

Table 3: Effect of LGG on chromosomal aberrations and meiotic index induced by AFs in spermatocytes in male mice.

\begin{tabular}{|c|c|c|c|c|c|c|c|c|c|}
\hline \multirow{2}{*}{$\begin{array}{l}\text { Experimental } \\
\text { Groups }\end{array}$} & \multirow{2}{*}{$\begin{array}{l}\text { Sperm } \\
\text { Count } \\
\left(\times 0^{6}\right)\end{array}$} & \multirow{2}{*}{$\begin{array}{l}\text { \% Sperm } \\
\text { Motility }\end{array}$} & \multicolumn{7}{|c|}{ \% Sperm Morphology } \\
\hline & & & Head Abnormality & $\begin{array}{l}\text { Mid-piece } \\
\text { Abnormality }\end{array}$ & Tail Abnormality & Decapitation & Agglutination & $\begin{array}{l}\text { Total } \\
\text { Abnormality }\end{array}$ & C.D. \\
\hline $\begin{array}{l}\text { Control } \\
\text { (Broth / corn oil) }\end{array}$ & $\begin{array}{l}21.9 \pm \\
0.94^{A B}\end{array}$ & $82.0 \pm 2.55^{\mathrm{A}}$ & $2.80 \pm 0.37^{A B}$ & $2.80 \pm 0.37^{A}$ & $2.40 \pm 0.25^{A}$ & $3.20 \pm 0.37^{A}$ & $0.20 \pm 0.20^{A}$ & $11.0 \pm 0.71^{\mathrm{A}}$ & $10.0 \pm 0.71^{A}$ \\
\hline $\begin{array}{l}\text { AFs } \\
(0.7 \mathrm{mg} / \mathrm{kg} \text { b.w. })\end{array}$ & $14.5 \pm 0.63^{c}$ & $34.0 \pm 1.87^{c}$ & $13.8 \pm 1.10^{c}$ & $20.4 \pm 0.51^{c}$ & $8.80 \pm 0.86^{c}$ & $19.6 \pm 0.93^{c}$ & $18.4 \pm 0.75^{\mathrm{C}}$ & $81.0 \pm 2.00^{C}$ & $40.8 \pm 1.43^{\mathrm{D}}$ \\
\hline $\begin{array}{l}L G G \\
\left(1 \times 10^{10}\right)\end{array}$ & $\begin{array}{l}25.2 \pm \\
0.93^{A B}\end{array}$ & $90.0 \pm 1.58^{\mathrm{A}}$ & $2.60 \pm 0.25^{\mathrm{AC}}$ & $2.40 \pm 0.25^{\mathrm{A}}$ & $2.40 \pm 0.25^{\mathrm{A}}$ & $2.60 \pm 0.25^{A}$ & $0.20 \pm 0.20^{A}$ & $10.0 \pm 0.71^{\mathrm{A}}$ & $5.60 \pm 0.51^{B}$ \\
\hline LGG plus AFs & $19.6 \pm 0.91^{\mathrm{A}}$ & $69.0 \pm 1.87^{B}$ & $6.20 \pm 0.58^{\mathrm{B}^{*}}$ & $9.20 \pm 0.59^{B}$ & $4.00 \pm 0.44^{\mathrm{A}}$ & $9.40 \pm 0.51^{\mathrm{B}}$ & $7.20 \pm 0.37^{\mathrm{B}}$ & $36.0 \pm 1.38^{\mathrm{B}}$ & $18.0 \pm 0.71^{c}$ \\
\hline
\end{tabular}

- Means with different superscript letters $(A, B, C \& D)$ are significantly different $(P<0.001)$

- Means with a star are significantly different $(P<0.05)$

-All data are expressed as means \pm SEM.

Table 4: Effect of LGG on AFs-induced changes in sperm parameters in male mice.

the AFs-treated mice, this difference was statistically highly significant at $\mathrm{P}<0.001$.

In mice receiving LGG before AFs-intoxication, different sperm abnormalities significantly reduced $(36.0 \%)$ in comparing with AFs-treated group at $\mathrm{P}<0.001$, this enhancement showed significant differences with respect with either control or LGG groups at $\mathrm{P}<0.001$. Head abnormalities showed a significant reduction at $\mathrm{P}<0.05$, with respect to AFs group. Also, mid-piece abnormalities, decapicitation and agglutination decreased significantly when compared with AFs group at $\mathrm{P}<0.001$. Meanwhile, tail abnormalities decreased to the baseline of control and showed no significant change when compared with LGG or control groups at $\mathrm{P}>0.05$. The retention of $\mathrm{CD}$, in LGG plus AFs group, showed a significant reduction $(18.0 \%)$ when compared with AFs-treated group $(\mathrm{P}<0.001)$, but it was still higher than that of control and LGG groups and statistical differences were shown at $\mathrm{P}<0.001$. Mice received LGG culture alone showed no significant changes in all types of sperm morphology (10.0\%) with respect to control $\mathrm{P}>0.05$. On the other hand, CD retention showed a significant reduction $(5.6 \%)$ when compared with the control group $(\mathrm{P}<0.001)$.

\section{Discussion}

The data obtained in this study show that AFs induce a significant increase in Lipid peroxidation (LPO) in liver and kidney tissues as increasing in malondialdehyde (MDA) production. MDA is an end product of lipid peroxidation, and is considered a late biomarker of oxidative stress and cellular damage, and LPO is one of the main manifestations of oxidative damage and it has been found to play an important role in the toxicity and carcinogenicity [43]. Oxidative stress arises when the generation of ROS, by-products of the oxidative metabolism primarily produced in the mitochondria, exceeds the cellular ability to eliminate them and to repair cellular damage, thus leading to oxidation of biomolecules including DNA, lipids and proteins [44]. These results confirm and extend previous data which have demonstrated that AFs induce a significant increase in MDA under in vitro and in vivo conditions $[15,45,46]$.

On the other hand, peroxidative damages are encountered by elaborate defense mechanisms, including enzymatic and nonenzymatic antioxidants [47]. To assess the balance of reactive oxygen species (ROS) production in liver and kidney, levels of non-enzymatic antioxidants GSH and enzymatic antioxidant (SOD) activity were measured. The increase in MDA can be attributed to the significant decrease in both non-enzymatic antioxidant (GSH) and the activity of antioxidant enzyme (SOD) in liver and kidney homogenates of mice treated with AFs. Our findings of decrease in GSH contents and the activities of SOD corroborate with that of previous studies [48-51]. Thus significant decrease in GSH level will further aggravate the toxic effects of these mycotoxins. GSH plays a critical role in the protection of tissues from $\mathrm{AFB}_{1}$ exposure by directly interacting with ROS or as a cofactor for enzymatic detoxification and the liver necrosis begins when the glutathione stores are almost exhausted $[47,52,53]$. GSH depletion might be a consequence of mycotoxin conjugation with GSH or/and continuous attack of free radicals which known to generate reactive intermediates (such as $\alpha, \beta$-unsaturated aldehydes) that covalently bind to GSH $[54,55]$. This supports the hypothesis that oxidative stress, which is always associated with lipid peroxidation, is a crucial step in aflatoxin $\mathrm{B}_{1}$-induced liver damage [56,57].

The pretreatment with LGG before intoxication with AFs ameliorated the oxidative status compared to control, where MDA level decreased and SOD activity increased, along with an increase in GSH contents. Many in vitro studies, reported that LAB strains possess antioxidant properties and inactivate ROS via enzymatic mechanisms, e.g. by a coupled NADH oxidase/ peroxidase system, superoxide dismutase and catalase [58-60]. The yoghurt bacteria Lactobacillus delbrueckii and Streptococcus thermophilus inhibited 
peroxidation of lipids through scavenging the reactive oxygen radicals, such as hydroxyl radical, or hydrogen peroxide [61]. Bifidobacterium longum ATCC 15708 and to a lesser extent L. acidophilus ATCC 4356 inhibited linoleic acid peroxidation and scavenged free radicals [62]. Also, it was found in human and animal studies that some LAB strains, which inactivate ROS, decrease biochemical parameters of oxidative stress [63,64]. In a clinical study, Songisepp et al. [65] reported that the healthy volunteers consumed $150 \mathrm{~g}$ of goat milk fermented with a starter culture Lactobacillus fermentum ME-3 for 21 days had shown important improvement of the overall antioxidant activity of blood, as well as antioxidant status, prolonged resistance of lipoprotein fraction to oxidation, reduced level of peroxide lipoproteins and oxidized LDL cholesterol, reduced level of glutathione redox ratio, and increased overall antioxidant activity. Moreover, some lactobacilli were reported to produce antioxidant factors in the human gastrointestinal tract [66]. Kullisaar et al. [67] had identified two Lactobacillus fermentum strains (E-3 and E-18) with antioxidative properties that overcome exo- and endogenous oxidative stress. The majority of milk bacteria show antioxidant behavior; eliminating the excess oxygen free radicals and producing superoxide dismutase, or glutathione [68] Chen et al. [69] reported that the selenium-enriched lactobacillus could elevate antioxidant-enzyme activities and reducing lipid peroxidation reaction, as well as inhibited excessive release of TNF-a preventing the dramatic elevation of $\left[\mathrm{Ca}^{2+}\right]$ in mice hepatocytes. In a recent study, Koller et al. [70] investigated the prevention of oxidative DNA damage in human derived colon (HT29) cells by 55 strains of lactic acid bacteria, they indicated that the reduction of oxidative damage was only seen with viable bacteria but not with heat inactivated cells and that it took place when the colon cells were separated from the LAB by permeable filter membranes indicating that the bacteria release ROS protective factors into the medium. Castex et al. [71] reported that shrimps with a diet enriched of Pediococcus acidilactici MA18/5M sustained higher antioxidant defences and lower oxidative stress level.

Concerning genotoxicity, the present results showed clearly that AFs were genotoxic in bone marrow and spermatocyte cells and had cytotoxic effects in both cell types. Moreover, they affected the DNA synthesis and chromosome segregation and progression through mitosis. AFs genotoxicity revealed by induction of structural (total structure abnormalities $\sim 12 \%$ ) and numerical (total numerical abnormalities $\sim 17.5 \%$ ) chromosome aberrations in somatic cells and (12.6\% for structure and $12.4 \%$ for numerical aberrations) in germ cells. In addition, AFs reduced the meiotic and mitotic activities. These findings coincide with previous reports; El-Arab et al. [72] reported that $\operatorname{AFs}\left(B_{1}, B_{2}, G_{1}\right.$ and $\left.G_{2}\right)$ induced structural and numerical chromosomal aberrations in bone marrow and germ cells of male mice. $\mathrm{AFB}_{1}$ has induced different chromosomal abnormalities in bone marrow cells and spermatocytes and shown to reduce the meiotic and mitotic activities of male Swiss albino mice [73,74]. In earlier study, the effect of oral consumption of $200 \mathrm{ppb}$ of crude AFs showed testicular degeneration and a decrease in the meiotic index [75]. Aneuploidogenic ability of $\mathrm{AFB}_{1}$ was reported and it appeared to affect assembly of tubulin into microtubules and/or bring about tubulin deplymerization and would result in generation of meiotic micro nucleate giant spermatocytes in Swiss mice [76], which may explain the high percentage of premature centromere division and aneuploidy found in this work. $\mathrm{AFB}_{1}$ genotoxicity might be caused through the formation of $\mathrm{AFB}_{1}$ DNA adducts, which is regarded as a critical step in the initiation of $\mathrm{AFB}_{1}$-induced hepatocarcinogenesis $[9,10]$. Moreover, several reports suggested that oxidative stress is considered to be related to cell injury and DNA damage induced by $\mathrm{AFB}_{1}$ through the generation of intracellular reactive oxygen species (ROS) $[12,16]$ In contradiction, the present results showed that the administration of LGG before AFs-intoxication reduced the AFs-induced genotoxicity (somatic and germ cells by around three folds) and cytotoxicity in both cell types. These data are consistent with other experimental studies which had evidenced the ability of lactobacilli and bifidobacteria to decrease the genotoxic activity of some chemical compounds [32,77,78]. Gratz et al. [79] used DNA fragmentation as a marker of $\mathrm{AFB}_{1}$-induced DNA damage in differentiated Caco-2 cells exposed to $\mathrm{AFB}_{1}$ following induction of $\mathrm{CYP}_{3 \mathrm{~A} 4}$. DNA damage was apparent following treatment with $\mathrm{AFB}_{1}$, while coincubation with LGG reduced the $\mathrm{AFB}_{1}$-induced damage in this test system.

Regarding the reproductive toxicity, the present study clearly indicated that oral administration of the AFs caused adverse effects on male reproductive parameters in mice (Table 3 ). These findings clearly indicated to severe impact of AFs on spermatogenesis and/ or spermiogenesis; and it is a clear reflection of a direct or indirect toxic manifestation of these mycotoxins treatment in the spermatogenic compartment. Various authors have reported similar kind of observations in different animals emphasizing AFs as reproductive toxicants; disruption of spermatogenesis $[80,81]$ and production of defective spermatozoa $[82,83]$ when Swiss mice were treated with $\mathrm{AFB}_{1}$, the most potent and potentially lethal metabolite.

ROS peroxidized fatty acids producing metabolites that could damage phosphatides of cell membrane; consequently, damage the sperm morphology and might impair sperm motility $[84,85,86]$. Consequently, the decline in sperm motility might be due to mitochondrial disruption and/or oxidative stress, where a fairly percent of mid-piece disruption was found, in addition to the deformation of the flagellum. These findings confirm the previous data correlating the decrease in human sperm motility to mitochondrial disruption and/ or an increase in lipid peroxidation [87]. Furthermore, Chitra et al. [88] observed that increased levels of lipid peroxidation caused the reduction of sperm count and viability. The sticky flagellum observed in this study might be formed by fusing of two or more spermatozoa, where two or more axonemes are in a common cytoplasm [83]. On the other hand, pretreatment with LGG significantly mitigates the mycotoxin-induced alterations in reproductive parameters in mice, where a significant improvement in the sperm motility and raise in the sperm number; along with reducing sperm abnormalities were shown. Moreover, these probiotic reduced CD retention by more 2 folds with respect to the mycotoxins-treated groups.

The overall data indicate that the LGG have a broad range of biomodulatory properties; alleviate the mycotoxins-oxidative stress and protect against their genotoxicity; as well as mitigate their spermatotoxic effects. This might be, in part, due to the ability of lactic acid bacteria to adsorb this mycotoxin; where several studies clearly reported the adsorption mechanisms in vitro [24,79,89]. Previous work showed that LGG was the most efficient strain in binding a range of mycotoxins, including aflatoxins [27]. Furthermore, Gratz et al. [90] suggested that LGG treatment reduced the hepatotoxic effects caused by a high dose of $\mathrm{AFB}_{1}$, by increasing the excretion of orally dosed aflatoxin via the fecal route and suggested that LGG was able to retain additional $\mathrm{AFB}_{1}$ and $\mathrm{AFM}_{1}$ inside the intestinal lumens of rats. Moreover, $\mathrm{LAB}$ found to cause reduction of the formation of secondary bile acids [91] and enhancement of the immune system [92-94].

In conclusion, the present data confirm the toxicity induced by aflatoxins; where the hepatotoxicity and nephrotoxicity were accompanied by an elevation in LPO along with a reduction in GSH 
Citation: Deabes MM, Darwish HR, Abdel-Aziz KB, Farag IM, Nada SA, et al. (2012) Protective Effects of Lactobacillus rhamnosus GG on AflatoxinsInduced Toxicities in Male Albino Mice. J Environment Analytic Toxicol 2:132. doi:10.4172/2161-0525.1000132

contents and SOD activity. Also, AFs induced genotoxicity in somatic and germ cells, as well as resulted in mitotic and meiotic delay. In addition, AFs caused severe spermatotoxic effects. By contrast, the current results indicate that oral administration of LGG cultures to mice significantly mitigates mycotoxin-induced toxicity by means of preventing oxidative stress, and by maintaining glutathione content, as well as a stable activity of SOD, and protected against mycotoxinsinduced genotoxicity and sperm toxicity. However, further studies are needed to better understand the in vivo possible mechanism(s) by which LGG may reduce the toxicity induced by this mycotoxin.

\section{References}

1. CAST (2003) Mycotoxins: risks in plant, animal and human systems. Task Force Report no. 139, Council for Agricultural Science and Technology Ames IA. 1-191.

2. Williams JH, Phillips TD, Jolly PE, Stiles JK, Jolly CM, et al. (2004) Human Aflatoxicosis in developing countries: a review of toxicology, exposure, potentia health consequences and interventions. Am J Clin Nutr 80: 1106-1122.

3. Wang JS, Groopman JD (1999) DNA damage by mycotoxins. Mut Res 424 167-181.

4. Wangikar PB, Dwivedi P, Neeraj, Sinha, Sharma AK, et al. (2005) Teratogenic effects in rabbits of simultaneous exposure to ochratoxin $A$ and aflatoxin B1 with special reference to microscopic effects. Toxicology 215: 37-47.

5. Abbès S, Ben Salah-Abbès J, Hetta MM, Abdel-Wahhab MA, Bacha $\mathrm{H}$, et al (2008) Efficacy of Tunisian montmorillonite for in vitro aflatoxin binding and in vivo amelioration of physiological alterations. Appl Clay Sci 42: 151-157.

6. IARC (1993) Aflatoxins. IARC Monogr Eval Carcinog Risks Hum 56: 243-395

7. Picha J, Cerovsky J, Pichová D (1986) Fluctuation in the concentration of sex steroids and aflatoxin B1 in the seminal plasma of boars and its relation to sperm production. Vet med 31: 347-357.

8. Ibeh IN, Saxena DK, Uraih N (2000) Toxicity of aflatoxin: effects on spermatozoa, oocytes, and in vitro fertilization. J Environ Pathol Toxicol Oncol 19: 357-361.

9. Sharma RA, Farmer PB (2004) Biological relevance of adduct detection to the chemoprevention of cancer. Clin Cancer Res 10: 4901-4912.

10. Preston RJ, Williams GM (2005) DNA-reactive carcinogens: mode of action and human cancer hazard. Crit Rev Toxicol 35: 673-683.

11. Pineaua P, Marchioa A, Battistonb C, Cordinaa E, Russob A, et al. (2008) Chromosome instability in human hepatocellular carcinoma depends on p53 status and aflatoxin exposure. Mutation Research 653: 6-13.

12. Towner RA, Qian SY, Kadiiska MB, Mason RP (2003) In vivo identification of aflatoxin-induced free radicals in rat bile. Free Radic Biol Med 35:1330-1340.

13. Berg D, Youdim M, Riederer P (2004) Redox imbalance. Cell Tissue Res 318 201-203.

14. Verma RJ, Mathuria N (2007) Curcumin ameliorates aflatoxin-induced lipid peroxidation in liver, kidney and testis of mice-an in vitro study. Acta Pol Pharm 64: 413-416.

15. Verma RJ, Mathuria N (2008) Curcumin ameliorates aflatoxin-induced lipidperoxidation in liver and kidney of mice. Acta Pol Pharm 65:195-202.

16. Theumera MG, Cánepaa MC, Lópezb AG, Marya VS, Dambolenac JS, et al (2010) Subchronic mycotoxicoses in Wistar rats: Assessment of the in vivo and in vitro genotoxicity induced by fumonisins and aflatoxin B1, and oxidative stress biomarkers status. Toxicology 268: 104-110.

17. FAO/WHO (2002) Guidelines for the evaluation of probiotics in food. Report of a joint $\mathrm{FAO} / \mathrm{WHO}$ working group on drafting guidelines for the evaluation of probiotics in food. London, Ont, Canada.

18. Ouwehand AC, Salminen S, Isolauri E (2002) Probiotics: an overview of beneficial effects. Antonie Van Leeuwenhoek 82: 279-89.

19. Saxelin M, Tynkkynen S, Mattila-Sandholm T, De Vos WM (2005) Probiotic and other functional microbes: from markets to mechanisms. Curr Opin Biotechnol 16: 204-211.

20. Kruszewska D, Lan J, Lorca G, Yanagisawa N, Marklinder I, et al. (2002) Selection of Lactic Acid Bacteria as probiotic strains by in vitro tests. Microb Ecol Health Dis 29: 37-49.
21. Haskard CA, El-Nezami HS, Kankaanpaa PE, Salminen S, Ahokas JT (2001) Surface binding of aflatoxin B1 by lactic acid bacteria. Appl Environ Microbio 67: 3086-3091.

22. Hwang KC, Lee W, Kim GY, Lee SK, Lee J, et al. (2005) The binding of aflatoxin B1 modulates the adhesion properties of Lactobacillus casei KCTC 3260 to a HT29 colon cancer cell line. Food Sci Biotechnol 14: 866-870.

23. Zinedine A, Faid M, Benlemlih M (2005) In vitro reduction of aflatoxin $B_{1}$ by strains of lactic acid bacteria isolated from Moroccan sourdough bread. Int Agr Biol 7: 67-70.

24. Shahin AAM (2007) Removal of aflatoxin B1 from contaminated liquid media by dairy lactic acid bacteria. Int J Agr Biol 9: 71-75.

25. Yan F, Polk DB (2002) Probiotic bacterium prevents cytokine induced apoptosis in intestinal epithelial cells. J Biol Chem 277: 50959-50965.

26. Yan F, Polk DB (2006) Probiotics as functional food in the treatment of diarrhea Curr Opin Nutr Metab Care 9: 717-721.

27. El-Nezami H, Kankaanpää P, Salminen S, Ahokas J (1998) Ability of dairy strains of lactic acid bacteria to bind a common food carcinogen, aflatoxin B1. Food Chem Toxicol 36: 321-326.

28. Pierides M, El-Nezami H, Peltonen K, Salminen S, Ahokas J (2000) Ability of dairy strains of lactic acid bacteria to bind aflatoxin M1 in a food model. J Food Prot 63: 645-50.

29. El-Nezami H, Mykkanen H, Kankaanpaa P, Salmine S, Ahokas J (2000) Ability of Lactobacillus and Propionibacterium strains to remove aflatoxin B1 from the chicken duodenum. J Food Prot 63: 549-52.

30. Pool-Zobel B, Bertram B, Knoll M, Lambertz R, Neudecker C, et al. (1993) Antigenotoxic properties of lactic acid bacteria in vivo in the $\mathrm{Gl}$ tract of rats. Nut Cancer 20: 271-281

31. Gratz S, Mykkänen H, Ouwehand AC, Juvonen R, Salminen S, et al. (2004) Intestinal mucus alters the ability of probiotic bacteria to bind aflatoxin B1 in Vitro. Appl Environ Microbiol 70: 6306-6308.

32. Burns AJR, Rowland LR (2004) Antigenotoxicity of probiotics and prebiotics on faecal water-induced DNA damage in human colon adenocarcinoma cells. Mutat Res 551: 233-243.

33. Mcgarr SE, Ridlon JM, Hylemon PB (2005) Diet, anaerobic bacteria metabolism, and colon cancer: a review of the literature. J Clin Gastroentero 39: 98-109.

34. Deabes MM, Aboelsoud NH, Abou El-Kassem TL (2011) In vitro Inhibition of growth and aflatoxin B1 production of Aspergillus flavus strain (ATCC 16872) by various medicinal plant essential oils. Macedonian Journal of Medical Sciences 4:345-350

35. El-Nezami H, Polychronaki N, Salminen S, Mykkänen H (2002) Binding rathe than metabolism may explain the interaction of two food grade Lactobacillus strains with zearalenone and its derivative b-zearalenol. Appl Environ Microbiol 68:3545-3549

36. Ohkawa H, Ohishi N, Yagi K (1979) Assay for lipid peroxides in animal tissues by thiobarbituric acid reaction. Anal Biochem 95: 351-358.

37. Beutler E, Dubon OB, Kelly M (1963) Improved method for the determination of blood glutathione. J Lab Clin Med 61: 882-888.

38. Marklund S, Marklund G (1974) Involvement of the superoxide anion radical in the autoxidation of pyrogallol and a convenient assay for superoxide dismutase. Eur J Biochem 47: 469-474.

39. Preston RJ, Dean BS, Galloway S, Holden H, McFee AF, et al. (1987) Mammalian in vivo cytogenetic assays : analysis of chromosome aberrations in bone marrow cells. Mutat Res 189: 157-165.

40. Evans EP, Breckon G, Ford CE (1964) An air-drying method for meiotic preparations for mammalian testes. Cytogenetics 3: 289-294.

41. Russo A (2000) In vivo cytogenetics: Mammalian germ cells. Mutation Res 455: 167-189.

42. Wyrobek AJ, Bruce WR (1975) Chemical induction of sperm abnormalities in mice. Proc Nat Acad Sci 72: 4425-4429.

43. Carampin P, Rosan S, Dalzoppo D, Zagotto G, Zatta P (2003) Some biochemica properties of melatonin and the characterization of a relevant metabolite arising from its interaction with $\mathrm{H}_{2} \mathrm{O}_{2}$. J Pineal Res 34:134-142. 
Citation: Deabes MM, Darwish HR, Abdel-Aziz KB, Farag IM, Nada SA, et al. (2012) Protective Effects of Lactobacillus rhamnosus GG on AflatoxinsInduced Toxicities in Male Albino Mice. J Environment Analytic Toxicol 2:132. doi:10.4172/2161-0525.1000132

44. Hwang ES, Kim GH (2007) Biomarkers for oxidative stress status of DNA lipids, and proteins in vitro and in vivo cancer research. Toxicology 229: 1-10.

45. Sirajudeen M, Gopi K, Tyagi JS, Moudgal RP, Mohan J, Singh R (2009) Protective Effects of Melatonin in Reduction of Oxidative Damage and Immunosuppression Induced by Aflatoxin B1-Contaminated Diets in Young Chicks. Environ Toxicol 26: 153-160.

46. Banu GS, Kumar G, Murugesan AG (2009) Ethanolic leaves extract of trianthema portulacastrum ameliorates aflatoxin B1 induced hepatic damage in rats. Indian J Clini Biochem 24: 250-256.

47. Janssen YM, Van Houten B, Borm PJ, Mossman BT (1993) Cell and tissue responses to oxidative damage. Lab Invest 69: 261-274.

48. Rastogi R, Srivastava AK, Rastogi AK (2001) Long term effect of aflatoxin B on lipid peroxidation in rat liver and kidney: Effect of picroliv and silymarine. Phytother Res 15: 307-310.

49. Lin WC, Liao YC, Liau MC, Lii CK, Sheen LY (2006) Inhibitory effect of CDAII, a urinary preparation, on aflatoxin $B_{1}$-induced oxidative stress and DNA damage in primary cultured rat hepatocytes. Food Chem Toxicol 44: 546-551

50. Choi KC, Chung WT, Kwon JK, Yu JY, Jang YS, et al. (2010) Inhibitory effects of quercetin on aflatoxin B1-induced hepatic damage in mice. Food Chem Toxicol 48: 2747-2753.

51. El-Agamy DS (2010) Comparative eVects of curcumin and resveratrol on aflatoxin $\mathrm{B}_{1}$-induced liver injury in rats. Arch Toxicol 84: 389-396.

52. Abdel-Wahhab MA, Aly SE (2003) Antioxidants and radical scavenging properties of vegetable extracts in rats fed aflatoxin contaminated diet. J Agric Food Chem 51: 2409-2414.

53. Abdel-Wahhab MA, Aly SE (2005) Antioxidant property of Nagilia sativa (Black cumin) and Syzygium aromaticum (Clove) in rats during aflatoxicosis. J App Toxicol 25: 218-223.

54. Duke RC, Ocius DM, Young JDE (1996) Sci Am 12, 79

55. Glaab V, Collins AR, Eisenbrand G, Janzowski C (2001) DNA damaging potential and glutathione depletion of 2-cyclohexenelone in mammalian cells, compared to food relevant 2-alkenals. Mutat Res 497: 185-197.

56. Bedard LL, Massey TE (2006) Aflatoxin $\mathrm{B}_{1}$-induced DNA damage and its repair. Cancer Lett 241:174-183.

57. Ozen H, Karaman M, Cifremio Y, Tuzcu M, Ozcan K, et al. (2009) Effectiveness of melatonin on aflatoxicosis in chicks. Res Vet Sci 86: 485-489.

58. Kullisaar T, Songisepp E, Mikelsaar M, Zilme K, Vihalemm T, et al. (2003) Antioxidative probiotic fermented goats' milk decreases oxidative stressmediated atherogenicity in human subjects. Br J Nutr 90: 449-456.

59. Bruno-Barcena JM, Andrus JM, Libby SL, Klaenhammer TR, Hassan HM (2004) Expression of a heterologous manganese superoxide dismutase gene in intestinal lactobacilli provides protection against hydrogen peroxide toxicity. Appl Environ Microbiol 70: 4702-4710.

60. Lee J, Hwang KT, Heo MS, Lee JH, Park KY (2005) Resistance of Lactobacillus plantarum KCTC 3099 from Kimchi to oxidative stress. J Med Food 8: 299-304.

61. Ling MY, Yen CL (1999) Antioxidative ability of lactic acid bacteria. J Agric Food Chem 47:1460-1466.

62. Lin MY, Chang FY (2000) Antioxidative effect of intestinal bacteria Bifidobacterium longum ATCC15708 and Lactobacillus acidophilus ATCC 4356. Dig Dis Sci 45:1617-1622.

63. Han W (2004) Improvement of an experimental colitis in rats by treatment with lactic acid bacteria producing superoxide dismutase. Am Gastroenterol Associat 577.

64. Han W, Mercenier A, Ait-Belgnaoui A, Pavan S, Lamine F, et al. (2006) Improvement of an experimental colitis in rats by lactic acid bacteria producing superoxide dismutase. Inflamm Bowel Dis 12: 1044-1052.

65. Songisepp E, Kals J, Kullisaar T, Mandar R, Hutt P, et al. (2005) Evaluation of the functional efficacy of an antioxidative probiotic in healthy volunteers. Nutr J 4:22-32.

66. Ljungh A, Lan J, Yanagisawa N (2002) Isolation, selection and characteristics of Lactobacillus paracasei subsp. paracasei F16. Microb Health Dis $314: 4-6$

67. Kullisaar T, Zilmer M, Mikelsaar M, Vihalemm T, Annuk H, et al. (2002) Two antioxidative lactobacilli strains as promising probiotics. Int J Food Microbio 72: 215-224.
68. Songisepp E, Kullisaar T, Hutt P, Elias P, Brilene T, et al. (2004) A new probiotic cheese with antioxidative and antimicrobial activity. J Dairy Sci 87: 2013-2017.

69. Chen CC, Louie S, Shi HN, Walker WA (2005) Preinoculation with the probiotic Lactobacillus acidophilus early in life effectively inhibits murine Citrobacter rodentium colitis. Pediatr Res 58: 1185-1191.

70. Koller VJ, Marian B, Stidl R, Nersesyan A, Winter H, et al. (2008) Impact of lactic acid bacteria on oxidative DNA damage in human derived colon cells. Food Chem Toxicol 46: 1221-1229.

71. Castex M, Lemaire $P$, Wabete N, Chim L (2010) Effect of probiotic Pediococcus acidilactici on antioxidant defences and oxidative stress of Litopenaeus stylirostris under Vibrio nigripulchritudo challenge. Fish Shellfish Immunol 28: 622-631.

72. Ezz El-Arab A, Girgis S, Hegazy E, Abd El-Khalek A (2006) Effect of dietary honey on intestinal microflora and toxicity of mycotoxins in mice. BMC Complementary Altern Med 6:1-13.

73. Hassanane MS, Abdel Aziz KB, Shebl MM, Amer M, Abdel Maksood N (2009) Genotoxic Study on Two Mold Inhibitors Widely Used in Egypt, I. Effect on Somatic Cells. J Appl Sci Res 5: 546-555.

74. Hassanane MS, Abdel Aziz KB, Shebl MM, Amer M, Abdel Maksood N (2009) Genotoxic Study on Two Mold Inhibitors Widely Used in Egypt, II. Effect on Germ Cells. Res J Cell Mol Biol 3: 1-11.

75. Sahay M (1993) Aflatoxin induced testicular degeneration and decreased meiotic index in Rattus norvegicus. Cytobios 75: 191-195.

76. Faisal K, Periasamy VS, Sahabudeen S, Radha A, Anandhi R, et al. (2008) Spermatotoxic effect of aflatoxin B1 in rat: extrusion of outer dense fibers and associated axonemal microtubule doublets of sperm flagellum. Reproduction 135: $303-310$

77. Tavan E, Cayuela C, Antoine JM, Trugnan G, Chaugier C, et al. (2002) Effects of dairy products on heterocyclic aromatic amine-induced rat colon carcinogenesis. Carcinogenesis 23:477-483.

78. Caldini G, Trotta F, Villarini M, Moretti M, Pasquini R, et al. (2005) Screening of potential lactobacilli antigenotoxicity by microbial and mammalian cell-based tests. Int J Food Microbiol 102: 37-47.

79. Gratz S, Wu QK, El-Nezami H, Juvonen RO, Mykkänen H, et al. (2007) Lactobacillus rhamnosus strain $\mathrm{GG}$ reduces aflatoxin $\mathrm{B} 1$ transport, metabolism, and toxicity in Caco-2 cells. Appl Environ Microbiol 73: 3958-3964.

80. Faridha A, Faisal K, Akbarsha MA (2006) Duration-dependent histopathological and histometric changes in the testes of aflatoxin B1-treated mice. J Endocrinol Reprod 10: 117-133.

81. Faridha A, Faisal K, Akbarsha MA (2007) Aflatoxin treatment brings about generation of multinucleate giant spermatids (symplasts) through opening of cytoplasmicbridges: lightand transmission electronmicroscopic study in Swiss mouse. Reprod Toxicol 24: 403-408.

82. Agnes VF, Akbarsha MA (2001) Pale vacuolated epithelial cells in epididymis of aflatoxin-treated mice. Reproduction 122: 629-641.

83. Agnes VF, Akbarsha MA (2003) Spermatotoxic effect of aflatoxin B1 in albino mouse. Food Chem Toxicol 41: 119-130.

84. Alvarez JG, Touchstone JC, Blascol JC, Storey BT (1987) Spontanous lipid peroxidation and hydrogen peroxide and superoxide in human spermatozoa: superoxide dismutase as major enzyme protectant against oxygen toxicity. $J$ Androl 18: 338- 348

85. Saradha B, Mathur PP (2006) Induction of oxidative stress by lindane in epididymis of adult male rats. Environ Toxicol Pharmacol 22: 90-96.

86. Hsieh YY, Chang CC, Lin CS (2006) Seminal malondialdehyde concentration but not glutathione peroxidase activity is negatively correlated with seminal concentration and motility. Int J Biol Sci 2: 23-29.

87. Lodish H, Berk A, Kaiser CA, Kreiger M, Scott MP, et al. ( 2003) Molecula Cell Biology. Scientific American Books, Freeman and Company, New York 5.

88. Chitra KC, Latchoumycandane C, Mathur PP (2003) Induction of oxidative stress by bisphenol A in the epididymal sperm of rats. Toxicology 185: 119-127.

89. Hernandez-Mendoza A, Garcia HS, Steele JL (2009) Screening of Lactobacillus casei strains for their ability to bind aflatoxin $B_{1}$. Food Chem Toxicol 47:10641068. 
Citation: Deabes MM, Darwish HR, Abdel-Aziz KB, Farag IM, Nada SA, et al. (2012) Protective Effects of Lactobacillus rhamnosus GG on AflatoxinsInduced Toxicities in Male Albino Mice. J Environment Analytic Toxicol 2:132. doi:10.4172/2161-0525.1000132

Page 9 of 9

90. Gratz S, Täubel M, Juvonen RO, Viluksela M, Turner PC, et al. (2006) Lactobacillus rhamnosus strain GG modulates intestinal absorption, fecal excretion, and toxicity of aflatoxin B1 in rats. Appl Environ Microbiol 72: 73987400 .

91. Mirasoli M, Roda A, Montagnani M, Azzaroli F, Roda E (2002) Cholic acid metabolism in human fecal cultures during diet supplementation with Lactobacillus rhamnosus GG. Minerva Gastroenterol Dietol 48: 45-49.

92. Wallace TD, Bradley S, Buckley ND, Green-Johnson JM (2003) Interactions of lactic acid bacteria with human intestinal epithelial cells: effects on cytokine production. J Food Prot 66: 466-472.

93. Schultz M, Linde HJ, Lehn N, Zimmermann K, Grossmann J, et al. (2003) Immunomodulatory consequences of oral administration of Lactobacillus rhamnosus strain GG in healthy volunteers. J Dairy Res 70: 165-173.

94. Bengmark S, Martindale R (2005) Prebiotics and synbiotics in clinical medicine. Nutr Clin Pract 20: 244-261. 